\title{
Perception of Computer Work Health Impact among Higher Education Students
}

\author{
László Berényi1 ${ }^{1 *}$ Bernadett Szolnoki², Lehel Zoltán Györfy³, Nikolett Deutsch ${ }^{4}$ \\ 1 Institute of Management Science, Faculty of Economics, University of Miskolc, H-3515 Miskolc, Egyetemváros, P. O. B. 21, Hungary \\ 2 Hantos Elemér Business and Regional Sciences Doctoral School, University of Miskolc, H-3515 Miskolc, Egyetemváros, P. O. B. 21, \\ Hungary \\ ${ }^{3}$ Faculty of Economics and Business Administration, Babes-Bolyai University, 400084 Cluj-Napoca, 1 Mihail Kogălniceanu str., \\ Romania \\ ${ }^{4}$ Department of Strategy and Project Management, Corvinus Business School, Corvinus University of Budapest, H-1093 Budapest, \\ 8 Fővám Square, Hungary \\ * Corresponding author, e-mail: szvblaci@uni-miskolc.hu
}

Received: 31 January 2020, Accepted: 11 May 2020, Published online: 16 October 2020

\begin{abstract}
Beyond professional and IT competencies, sufficient computer work requires adequate workplace design. Applying ergonomic aspects in design and utilization aims to establish and maintain the man-machine system while considering long term impacts. However, the human body is quite adaptive to health-disadvantaged work postures, and it may be adversely affected, which leads to a decrease in work performance as well. This study investigates the relationship between computer use habits, workplace design, work environment, and perceived health impacts among higher education students. The study aims to find the critical factors of computer work for establishing ergonomic development actions. The results are based on the responses of 711 business students from various higher education institutions in Hungary, using a voluntary online survey. Cross-tabulation, ANOVA, and correlation analyses could show that exposition to the risk by workload and wrong workplace selection go together with more health problems. The results show that portable computers are preferred, sitting posture is usually wrongly chosen, tiredness in the upper body is common, but students rated their workplace design rather good. The main experience of the study is that targeted actions are required for protecting the health and improve efficiency in performing computer activities.
\end{abstract}

\section{Keywords}

computer work, ergonomics, health impacts, workplace design, sitting posture

\section{Introduction}

Computers are all around us during work and leisure activities. Office and administrative work, keeping business or personal contacts as well as learning are typically carried out with the support of personal computers that generate new challenges (Davis, 2012; Dix, 2017; York and Pendharkar, 2004; Zemke et al., 2013). Nowadays, these tasks increasingly require human-computer interactions.

Activities carried out by a personal computer can be considered as computer work regardless of the fact whether it is work or not since the physiological impacts are the same. The spread of desktop PCs in the 1980s was followed by mobile computers during the following decades, and nowadays, the penetration of smartphones is relevant, with computers moving from machine rooms into the pocket (Dix, 2017). Since technology is continuously developing, the functioning and structure of the human body are constant. Although performing a job, communication, or entertainment tasks can be carried out more efficiently (i.e., faster, more comfortable, more complex, and so forth), the structure of the human body may be affected adversely. Harmful disorders strike back in different forms, among others, reduced job performance, and lower quality of life. Therefore, both at home and work, there is a need for special attention to improving work conditions.

In a simplified approach, it can be stated that computer work is a civilization disease of the information society. Managing human-computer interactions requires a comprehensive approach that links the knowledge of engineering, social, medical, computer, and other sciences in line 
with the recent trends and challenges (Baranyi et al., 2003; Dix, 2017). Education and training people to the proper use of computers is of increasing importance.

\section{Problem formulation}

\subsection{Impacts of computer work}

Human-computer interactions have several physiological consequences already in the short term. Eye dryness (Rosenfield, 2011) is an early symptom that distracts attention from work and reduces performance. A durable and repeating load to the eyes can lead to irreversible harm.

Since computer work requires a special sitting posture, static muscular load (McKeown, 2008) is intensified. This load is especially evident in shoulders, arms, neck, and fingers (Larsen et al., 2009; Mork and Westgaard, 2007; Seghers et al., 2003; Wærsted et al., 2010; Yang and Cho, 2012), or collectively called Computer Vision Syndrome (CVS) (Anshel, 2005; Gowrisankaran and Sheedy, 2015; Teo et al., 2019; Turgut, 2018).

Long term impacts are usually developed because of the repeated exposure to short term load. Anshel (2005) highlights that eyes have a unique role because computer work is a high visually demanding task, and a sharp visual field is limited; musculoskeletal problems can be traced back to the need for ensuring a proper viewing position. Some symptoms are summarized in Table 1 based on Corlett et al. (1986), Kroemer and Kroemer (2001), Kroemer et al. (2001), and Yang et al. (2013).

\subsection{An ergonomic approach to workplace design}

Relevant literature in the field agrees that the source of the problems can be led back to the inadequate formation of computer workplace, especially sitting position, having a significant impact both on the job performance and the health (Khan et al., 2012; Kroemer and Kroemer, 2001; Laeser et al., 1998; Robertson et al., 2009; Shikdar and Al-Kindi, 2007). Beyond these impacts, other environmental factors like lighting, noise, or visual, temperature distractions also have a relevant effect (Assimakopoulos et al., 2008; De Korte et al., 2007; McKeown, 2008). Shikdar and Al-Kindi (2007) found a positive and significant correlation between worker health symptoms and workstation facilities, and inadequate workstation facilities contributed to more health problems. The research of Alexander and Currie (2004) clearly denoted that managing the issues must be started in childhood.

Accomplishing a comprehensive analysis is challenging due to the interdisciplinary characteristic and the conflict between system approach and itemized analysis
Table 1 Features of body parts loaded during office work

\begin{tabular}{lcc}
\hline Body part & Symptom & Reason \\
Vertebral & $\begin{array}{c}\text { Bend, blunt back pain, } \\
\text { torpidity, radiant pain } \\
\text { in limbs }\end{array}$ & $\begin{array}{c}\text { Not the appropriate } \\
\text { height of the desk or } \\
\text { chair. Wrong positioning } \\
\text { of the keyboard } \\
\text { and mouse. }\end{array}$ \\
Bad body posture.
\end{tabular}

Source: Based on Berényi et al. (2015)

(Nag, 2019). The challenge of finding solutions for harmonizing performance and related health issues can be supported by the continuously developing knowledge base of ergonomics (human factors). An early definition of ergonomics (Murrell, 1965) describes it as the relationship between man and his work environment, including the tools and materials, methods of work, and the organization as well as the nature of the man, the abilities, capacities, and limitations. The ergonomic approach means taking a total view of the whole work system (Fig. 1).

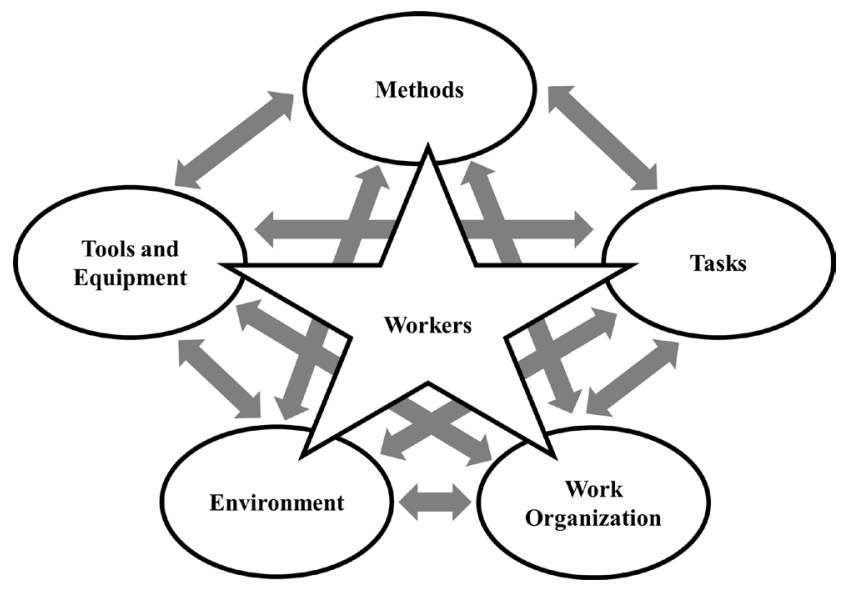

Fig. 1 A total view of the whole work system Source: Based on Anshel (2005) 
Kearney (2008) marks the benefits of ergonomic design as improved design, improved safety, and legal compliance. The consequences of not using an ergonomic design are, among others, lost time, increased cost level, injury, disease, and lost quality.

Office ergonomics (Kroemer and Kroemer, 2001; McKeown, 2008) emerged together with software ergonomics (Turner and Karasek, 1984) from the 1980s. These approaches deal with two aspects of the same topic. Software ergonomics raises the importance of interaction design beyond product design (Rogers et al., 2011).

Proper sitting posture for computer work is just one yet critical segment of office ergonomics. It is almost impossible to fulfill these requirements, particularly at home and with a notebook (Asundi et al., 2012; McKeown, 2008).

\subsection{System approach to the problem}

The human tolerance to the inadequate work environment is critical to health without a direct effect on work performance in the long term. Khurana (2009) pointed out that the change in working conditions correlates only weakly with performance. Understanding the impacts of the actions needs a system approach of ergonomics (Wilson, 2014). Fig. 2 presents an optimal chain of impacts according to a job. Based on the knowledge of the tasks derived from external requirements, the ergonomics of computer work (including, e.g., tools, layout, and timing) can be established that leads to appropriate corporate results through personal performance (work performance and health). Nevertheless, establishing a proper work environment usually needs investments and additional funding. Therefore, the changes in tasks or performance expectations rarely lead to the necessary adjustments to the work environment.
Fig. 2 also suggests the root cause of the performance and health problems related to computer work: workplace design usually does not strictly follow the requirements of the tasks and respects physiological needs. These issues are considered parallel and independent from each other, which leads to excessive loads. Both muscular and mental load are unavoidable during the activities, the complete elimination of them is inaccessible, but minimizing the extra-load may be possible. Moreover, office work is usually not exclusively computer work, and there are several accessories and office supplies that occupy the same place necessary for ideal computer workplace design.

\section{Research design}

\subsection{Goals}

An increase in time spent with computers leads to enhanced impacts. Both exhaustion and irreversible changes in health lead to lower job performance and a worse quality of life. The future generations are prepared for computer work, but ergonomic aspects are often neglected. A conscious approach may be missing because harmful impacts occur only later.

The study aims to explore higher education students' computer usage habits, including time spent with computers or smartphones and the ergonomics of the computer work environment at home. Evaluation of conformity is based on self-declarations about the exhausting characteristic of computer work and the harm affected. Exploring the critical practices of computer use may lead to improvement actions. Higher education institutions have a great opportunity to draw students' attention and show best practices through learning materials.

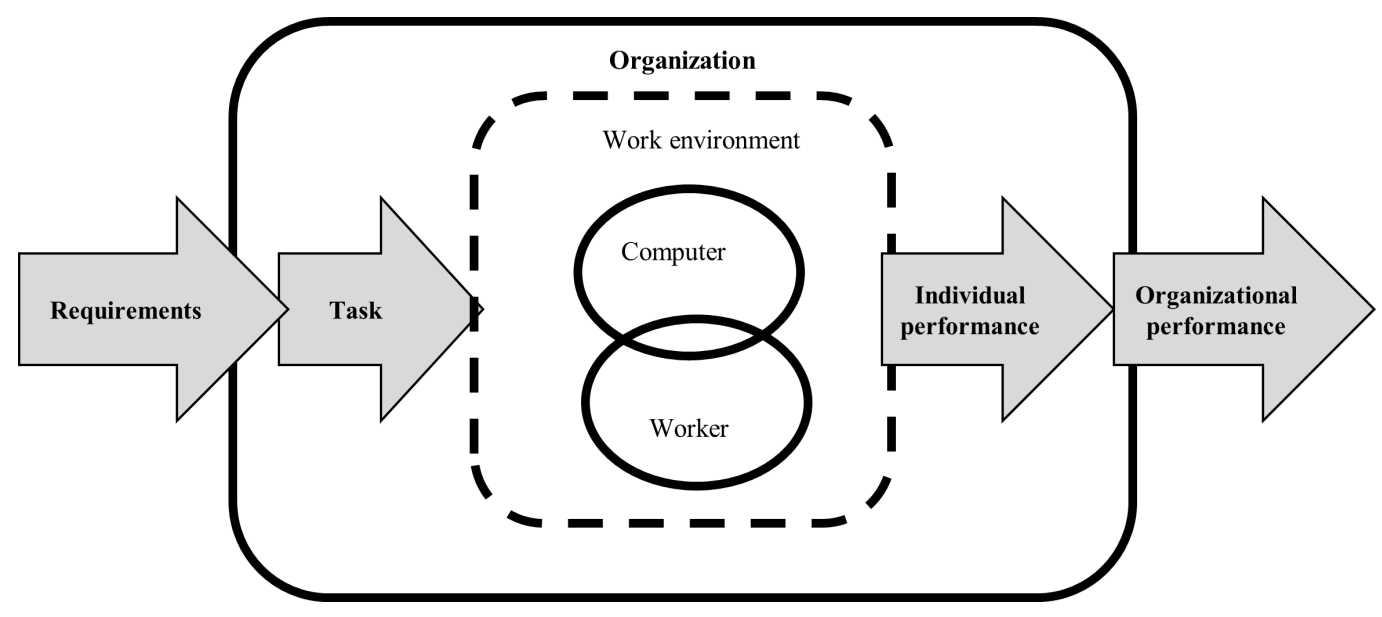

Fig. 2 The role or work environment in achieving good performance Source: Berényi (2013) 


\subsection{Presumptions and survey design}

The concept of the research accepts that computer work leads to unfavorable health impacts that show a relation with the design of the workplace. There are five presumptions formulated for detailed study:

- Mobilization is general in computer use.

- Workplace design is not ideal for computer use.

- Non-ideal workplace design correlates with the perception of health problems.

- There are significant differences by gender, age, study level, and work experience of the respondents in the survey results.

- There are significant relationships between the characteristics of workload, workplace design, and health impacts.

The questionnaire is designed for a comprehensive data collection about computer use habits, attitudes, ergonomic issues of computer workplace, and health impacts (Table 2).

According to the presumptions, the study draws a picture of:

- time spent with Info-Communication Tools (ICT),

- mobilization of ICT use,

- harms and health care problems affected by computer work,

- satisfaction with computer work and the design of the workplace,

- design of workplace and environment, including room type, computer type, and sitting position.

Data analysis is supported by IBM SPSS 22. Beyond descriptive statistics, analysis of relationships uses cross-tabulation, ANOVA (Kruskal-Wallis test), and correlation analysis are conducted where applicable.

\subsection{Research sample and limitations}

The research sample consists of the responses of 711 Hungarian higher education students who are studying in business economics. The data collection period ran from fall 2017 to the end of 2018. The sample characteristics are summarized in Table 3.

$62.4 \%$ of respondents are females $(n=444), 37.6 \%$ are males $(n=267)$. The average age is 22.9 years (Fig. 3 ). Respondents between 19 to 25 years old are overrepresented $(80.87 \%)$.

636 students $(89.4 \%)$ studies at the level of higher education vocational training or bachelor (these programs have several joint courses) and $75(10.6 \%)$ at the master
Table 2 Questioner

\begin{tabular}{|c|c|}
\hline Question & Options \\
\hline Gender & $\begin{array}{l}\text { male } \\
\text { female }\end{array}$ \\
\hline Age & year of birth \\
\hline $\begin{array}{l}\text { What is the level of your } \\
\text { studies? }\end{array}$ & $\begin{array}{l}\text { higher vocational } \\
\text { bachelor } \\
\text { master } \\
\end{array}$ \\
\hline $\begin{array}{l}\text { Do you have any work } \\
\text { experience? }\end{array}$ & $\begin{array}{l}\text { none } \\
\text { internship } \\
\text { employed }\end{array}$ \\
\hline $\begin{array}{l}\text { How many hours do you spend } \\
\text { using the following devices } \\
\text { in a day? }\end{array}$ & $\begin{array}{c}\text { desktop computer (hours) } \\
\text { notebook (hours) } \\
\text { tablet (hours) } \\
\text { smartphone (hours) } \\
\text { watching TV (hours) }\end{array}$ \\
\hline $\begin{array}{l}\text { What are your typical activities } \\
\text { with a desktop computer or } \\
\text { a notebook? } \\
\text { (multiple selections) }\end{array}$ & $\begin{array}{l}\text { chat, watching movies, reading } \\
\text { news, games, visiting social } \\
\text { sites, e-mail, checking time } \\
\text { plans, working, reading learning } \\
\text { materials, maps and route } \\
\text { planning, purchasing, video } \\
\text { telephony, listening to music }\end{array}$ \\
\hline $\begin{array}{l}\text { What are your typical activities } \\
\text { with a smartphone? } \\
\text { (multiple selections) }\end{array}$ & $\begin{array}{l}\text { chat, watching movies, reading } \\
\text { news, games, visiting social } \\
\text { sites, e-mail, checking time } \\
\text { plans, working, reading learning } \\
\text { materials, maps and route } \\
\text { planning, purchasing, video } \\
\text { telephony, listening to music }\end{array}$ \\
\hline $\begin{array}{l}\text { Are you satisfied with the } \\
\text { following factors in your } \\
\text { computer work environment? } \\
\text { (6-point scale, 1: not at all, } \\
\text { 6: fully) }\end{array}$ & $\begin{array}{c}\text { ergonomics of tools } \\
\text { size of desk } \\
\text { available space } \\
\text { light } \\
\text { sitting position } \\
\text { temperature } \\
\text { air freshness } \\
\text { general satisfaction with computer } \\
\text { workplace }\end{array}$ \\
\hline $\begin{array}{l}\text { Do you feel tired or harmed } \\
\text { during computer-work? } \\
\text { (6-point scale, 1: not at all, } \\
6 \text { : typical) }\end{array}$ & $\begin{array}{c}\text { Eyes } \\
\text { Hands and arms } \\
\text { Fingers } \\
\text { Back and shoulders } \\
\text { Neck } \\
\text { Waist }\end{array}$ \\
\hline $\begin{array}{l}\text { Do you feel computer work } \\
\text { exhausting? }\end{array}$ & $\begin{array}{c}\text { 6-point scale, } 1 \text { : not at all, } \\
\text { 6: very much }\end{array}$ \\
\hline
\end{tabular}

level. 539 of them $(75.8 \%)$ are full-time students. 330 students $(46.4 \%)$ have a job or internship work experience.

The reliability test of the survey is good. Cronbach Alpha, in the case of the evaluation of health impacts, is $0.825(n=8)$, and in the case of the assessment of the working environment, it is $0.845(n=7)$.

The limitations of the research are derived from the complexity of the topic and the sample collection method:

- Data collection uses a voluntary online survey managed by the EVASys Survey Automation Software. 
Table 3 Sample characteristics

\begin{tabular}{lccc}
\hline $\begin{array}{l}\text { Grouping } \\
\text { factor }\end{array}$ & Frequency & Percent \\
\hline Gender & male & 267 & $37.6 \%$ \\
& higher vocational & 444 & $62.4 \%$ \\
\hline Level of & bachelor & 485 & $21.2 \%$ \\
studies & master & 75 & $15.2 \%$ \\
& none & 329 & $46.3 \%$ \\
Work & internship & 330 & $46.4 \%$ \\
experience & employed & 52 & $7.3 \%$ \\
\hline & desktop computer & 131 & $18.4 \%$ \\
Computer type & notebook & 485 & $68.2 \%$ \\
used at home & both & 74 & $10.4 \%$ \\
& only smartphone or tablet & 21 & $3.0 \%$ \\
\hline & never & 51 & $7.2 \%$ \\
Use of mobile & rarely & 68 & $9.6 \%$ \\
internet access & frequently & 275 & $38.7 \%$ \\
& continuously & 317 & $44.6 \%$ \\
\hline
\end{tabular}

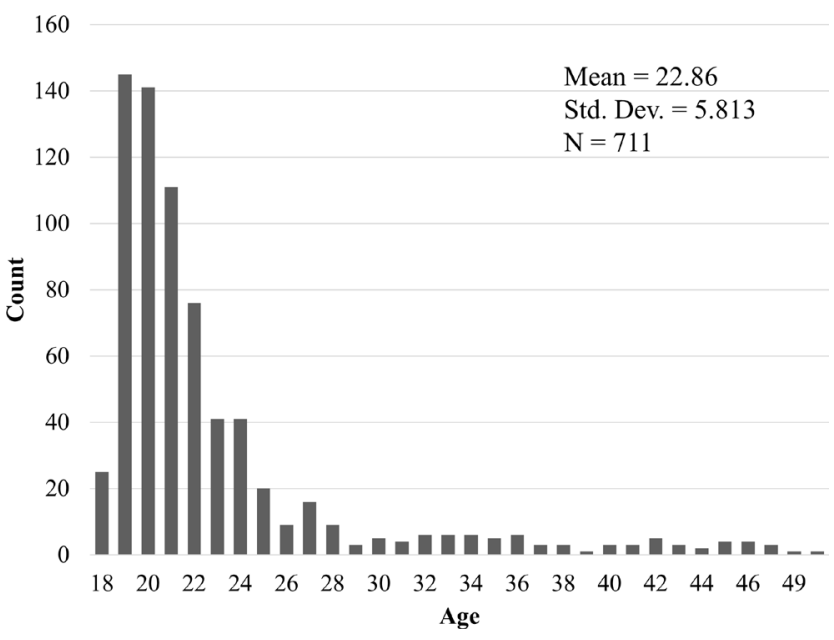

Fig. 3 Distribution of the sample by age

The analysis uses self-declared responses that may result in bias. The size of the sample $(n=711)$ can moderate this effect.

- The sample consists of Hungarian business students from various universities. The representativeness of the sample is not checked. However, the questions are not profession-specific; a generalization of the conclusion is not possible.

- The composition of the sample by age must be considered, 19 to 25 years old respondents are overrepresented.

- Investigation of workplace design and work environment is limited to the home.

\section{Results and discussion}

\subsection{Computer use and activities}

Students prefer notebooks (Fig. 4), and $68.2 \%$ use this type of computer at home. Both desktop and portable computers are used by $10.4 \%$, while only smartphones or tablets are marked by $3.0 \%$.

Based on the mean values (Table 4), the time spent with desktop computers (4.48 hours per day) exceeds the value of notebooks ( 3.27 hours per day). Those who use a tablet spend 2.12 hours per day with it. Smartphones are the most popular (5.55 hours per day), while 2.06 hours are spent watching TV.

The popularity of mobile internet access is remarkable. $38.7 \%$ of the respondents are frequent users, and $44.6 \%$ of them are continuously connected.

The survey asked to mark the most typical activities of the respondent on a list. The most preferred activities with computers are reading learning materials (marked by $87.1 \%$ of the respondents), watching a movie (73.6\%), and managing e-mails $(68.21 \%)$. The top list of the purposes for smartphone use includes chat $(90.1 \%)$, visiting social sites $(83.3 \%)$, and listening to music $(77.3 \%)$. Working with computers is marked by $47.4 \%$, while the value is $12.2 \%$ in the case of smartphones.

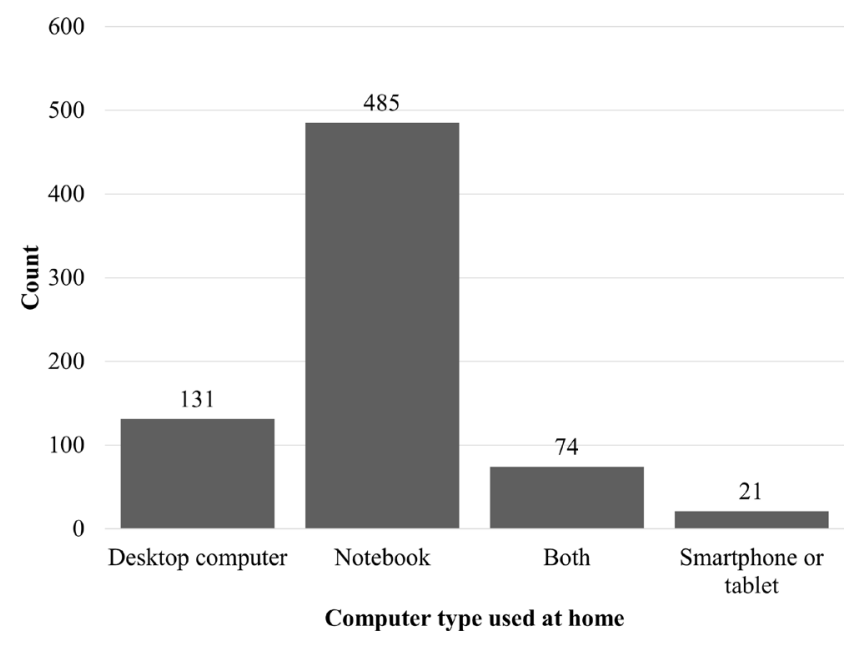

Fig. 4 Computer type used by the respondents

Table 4 Time spent with different devices (hours per day)

\begin{tabular}{lccc}
\hline & $N$ & Mean (hours) & Std. Deviation \\
\hline Desktop computer & 311 & 4.4759 & 2.8813 \\
Notebook & 515 & 3.2699 & 2.5213 \\
Tablet & 115 & 2.1217 & 1.8120 \\
Smartphone & 699 & 5.5494 & 3.8717 \\
TV & 454 & 2.0573 & 1.7266 \\
\hline
\end{tabular}




\subsection{Exhausting characteristic and health impact}

Exhausting nature of computer work (Fig. 5) is measured on a 6-point scale (a higher value means a higher level of tiredness).

$40.6 \%$ of the students deem computer work rather exhausting, but only $4.4 \%$ feel it very much exhausting.

Diagnosed health problems are perceived by $13.4 \%$ of the respondents, primarily the deterioration of vision. $24.5 \%$ marked that the answer "I do not know". However, the respondents feel healthy, and the detailed analysis foreshows several problems. Stretching and relaxing during computer work is occasional by $53.3 \%$ and regular by $41.9 \%$.

The survey asked to mark the level of getting tired (harmed) during computer work with a 6-point scale (higher value means the higher occurrence of the problem). Figs. 6 to 11 show the distribution of the responses and Table 5 summarizes the descriptive statistics. The tiredness of the eyes is the most common problem among the

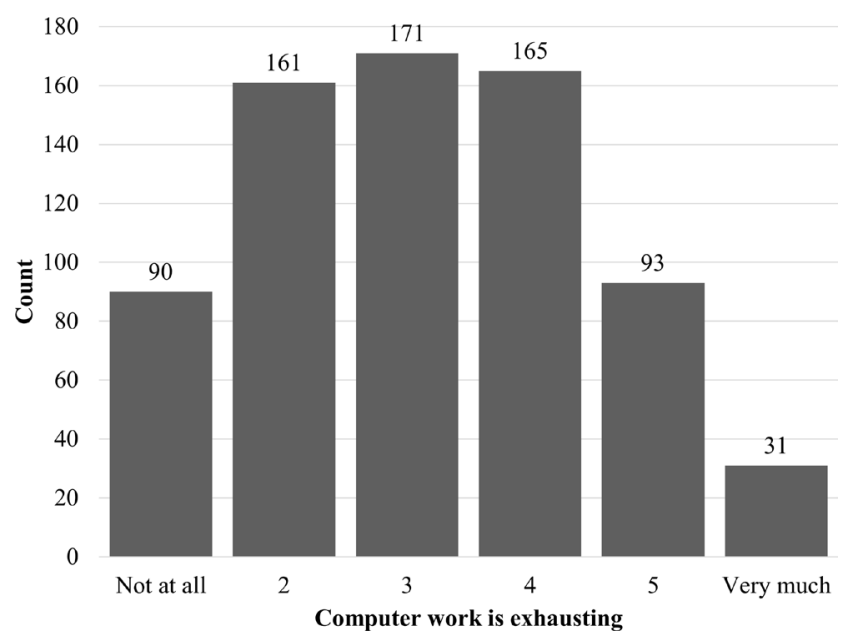

Fig. 5 Computer work felt exhausting (6-point scale)

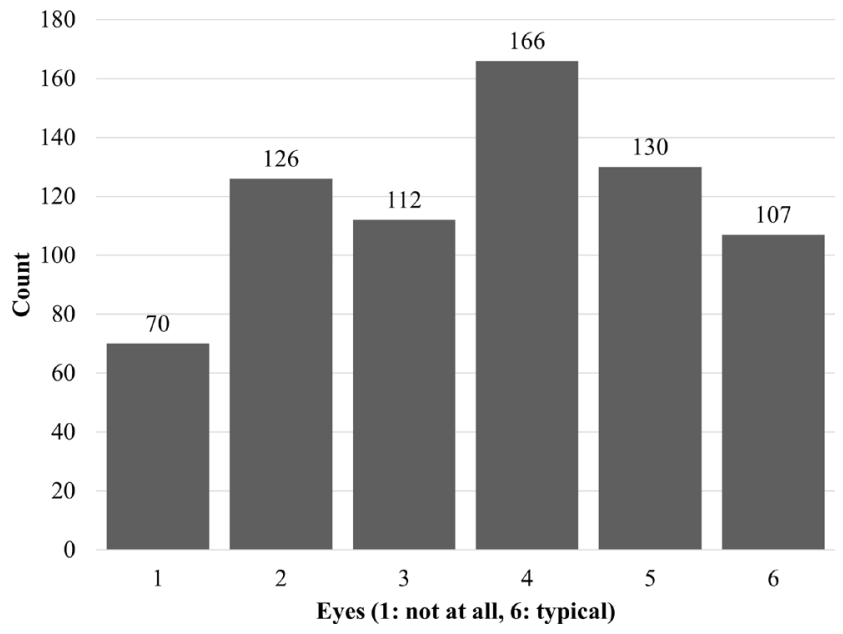

Fig. 6 Feeling tired in the eyes (6-point scale)

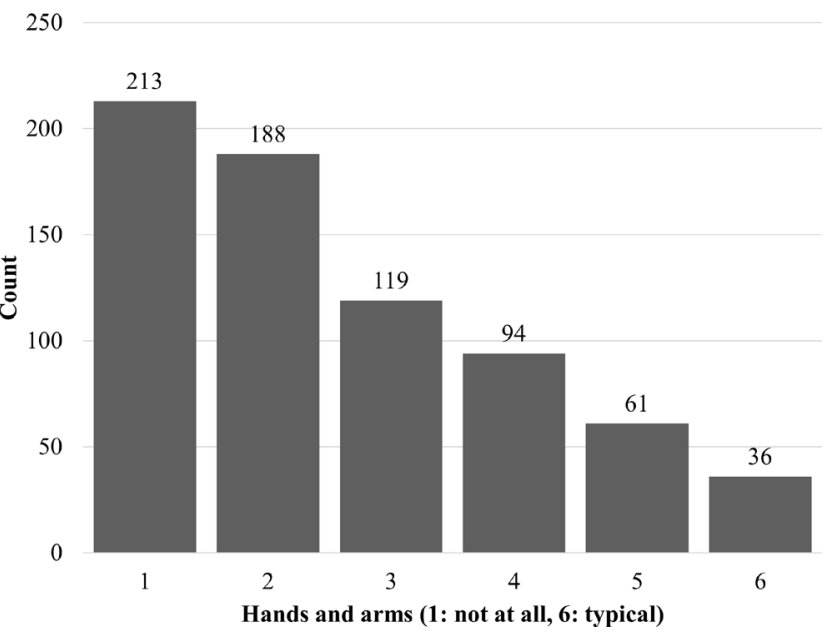

Fig. 7 Feeling tired in the hands and arms (6-point scale)

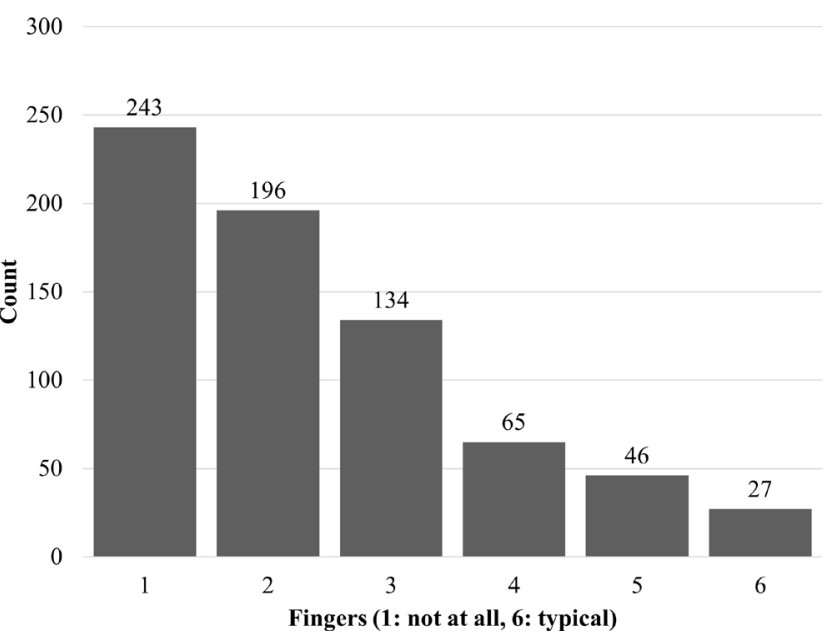

Fig. 8 Feeling tired in the fingers (6-point scale)

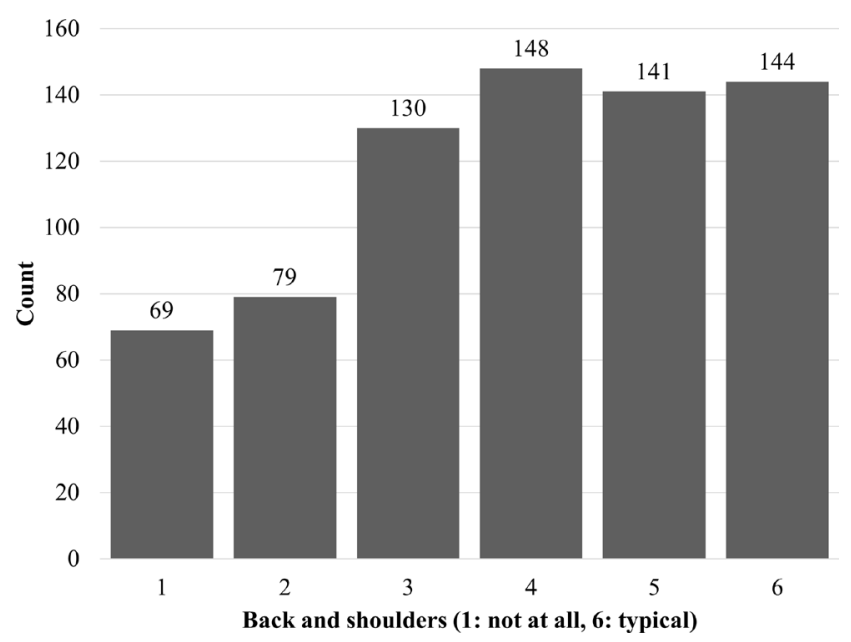

Fig. 9 Feeling tired in the back and shoulders (6-point scale)

students. More of them reported that the changes are permanent (e.g., need for eyeglasses, or frequent headaches). Back and waist problems are also remarkable. 


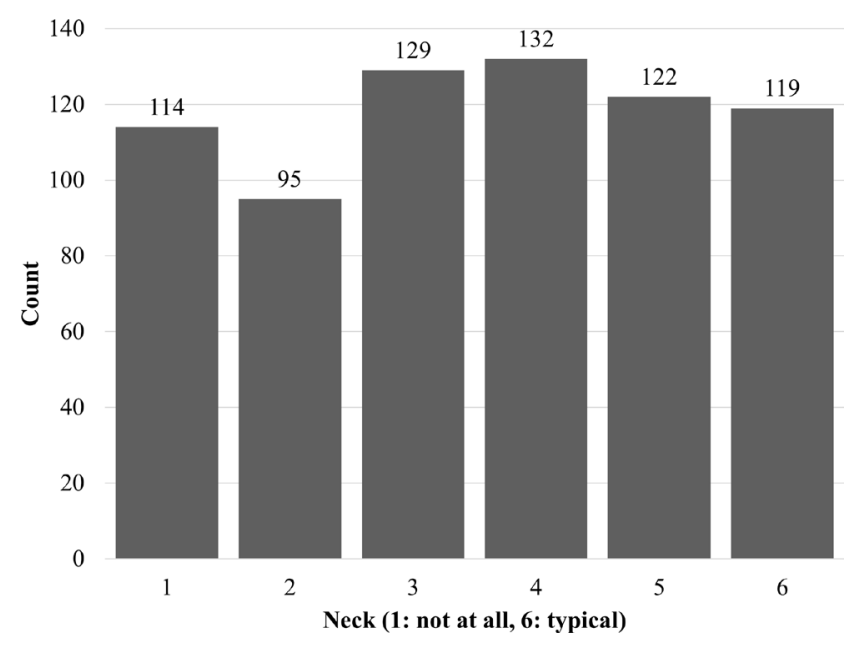

Fig. 10 Feeling tiredness in the neck (6-point scale)

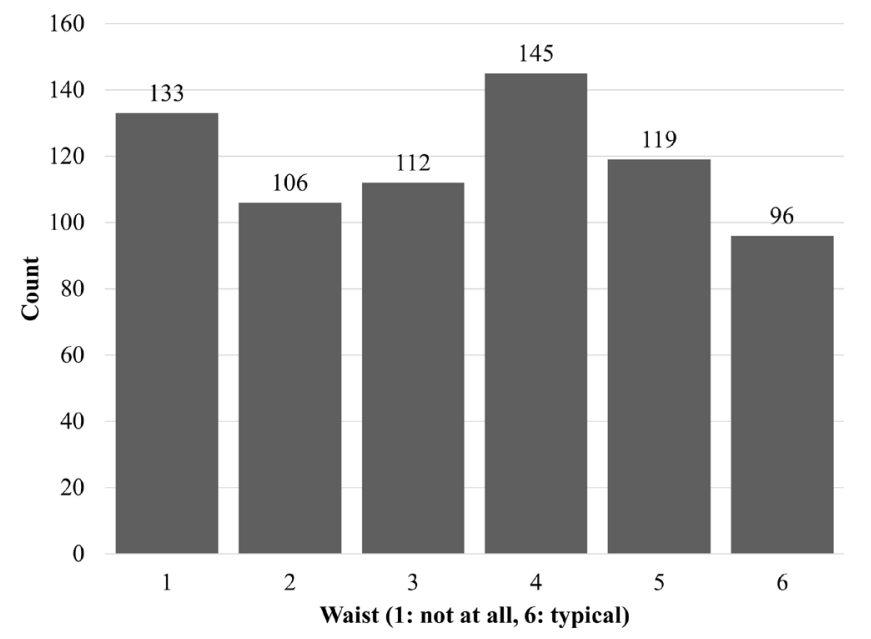

Fig. 11 Feeling tired in the waist (6-point scale)

Table 5 Getting tired or harmed of computer work (6-point scale)

\begin{tabular}{lccc}
\hline & $N$ & Mean & Std. Deviation \\
\hline Eyes & 711 & 3.6765 & 1.5608 \\
Hands and arms & 711 & 2.5921 & 1.4935 \\
Fingers & 711 & 2.3755 & 1.3955 \\
Back and shoulders & 711 & 3.9072 & 1.5824 \\
Neck & 711 & 3.5767 & 1.6807 \\
Waist & 711 & 3.4205 & 1.6772 \\
\hline
\end{tabular}

\subsection{Workplace design}

The analysis of workplace design and work environment includes room type, desk type, and chair characteristics. The most common location for computer work is a bedroom (66.5\%). The living room is used by $19.0 \%$ and a working room only by $9.4 \%$ of the respondents (Fig. 12).

$52.5 \%$ prefer a writing desk, $7.6 \%$ use a special computer desk. $25.7 \%$ do not use a desk for computer work, most of them keep their notebooks on their

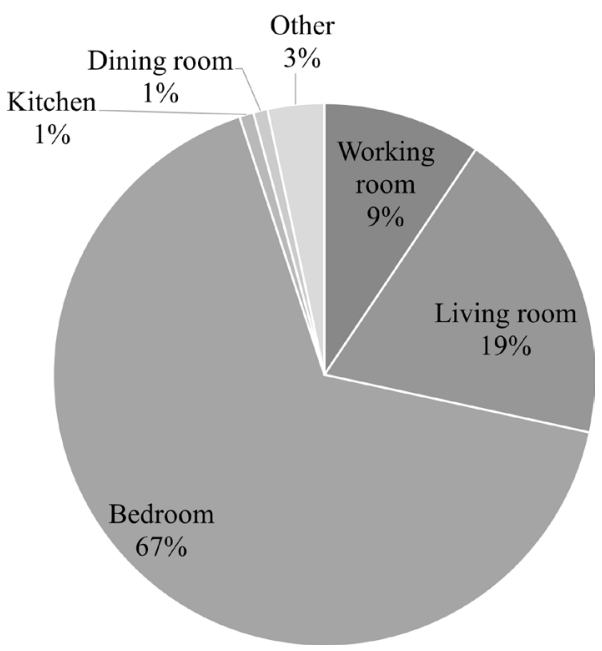

Fig. 12 Location of computer work

lap. An ergonomic chair (Kroemer and Kroemer, 2001; Woo et al., 2016) is a rolling one and has a low backrest. $55.1 \%$ of the respondents use a rolling chair. Nevertheless, the low backrest is preferred only by $8.4 \%$. Furthermore, $15.8 \%$ use armchair for computer work.

The standard equipment of the work environment incorporates (marked by the $\%$ of the respondents) desktop phone (62.7\%), desk lamp (55.7 \%), some tissues (51.2 \%), pencil case (48.5\%), and stationery (46.7\%).

It is important to consider satisfaction with the work environment. Results show that the respondents are very satisfied with the factors of the environment regardless of the room and desk type used (Table 6 and Fig. 13 show the mean values measured on a 6-point scale). Cross-tabulation shows remarkable differences between sitting position and room type (Pearson chi-square $=37.424, d_{f}=25$, sig. $=0.053$, not significant at $95 \%$ ), air freshness and room type $\left(\right.$ Pearson chi-square $=38.133, d_{f}=25$, sig. $=0.045$, significant), and available space and desk type (Pearson chisquare $=47.483, d_{f}=25$, sig. $=0.078$, not significant).

Table 6 Descriptive statistics of satisfaction with the work environment (6-point scale)

\begin{tabular}{lccc}
\hline & $N$ & Mean & Std. Deviation \\
\hline Ergonomics of tools & 711 & 4.5527 & 1.0732 \\
Size of desk & 711 & 4.6723 & 1.3219 \\
Available space & 711 & 4.7806 & 1.2726 \\
Light & 711 & 4.7707 & 1.1758 \\
Sitting position & 711 & 4.6118 & 1.2918 \\
Temperature & 711 & 4.9044 & 1.1552 \\
Air freshness & 711 & 4.9550 & 1.1350 \\
Computer work is & 711 & 3.1449 & 1.3646 \\
exhausting & & & \\
\hline
\end{tabular}




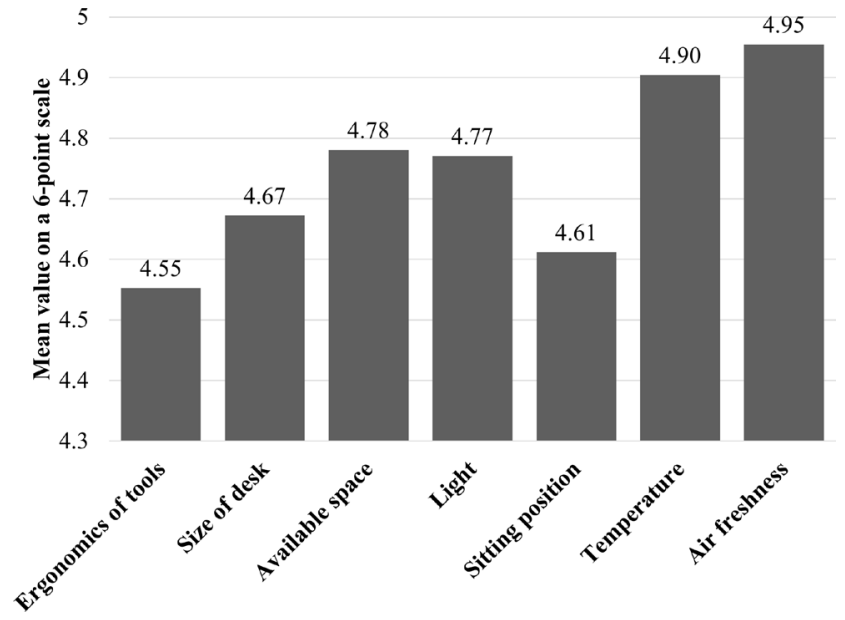

Fig. 13 Satisfaction with the work environment (6-point scale)

\subsection{Analysis of the relationship}

The question emerges whether there is a relationship between various grouping factors and the characteristics of computer work. Gender, level of studies, work experience, were used as the primary grouping factors. The results of the cross-tabulation analysis show the following significant results.

Gender shows significant relation with computer type (Pearson chi-square $=43.424, d_{f}=3$, sig. $=0.000$ ), room type (Pearson chi-square $=11.556, d_{f}=3$, sig. $\left.=0.041\right)$, table $($ desktop) type (Pearson chi-square $=49.653, d_{f}=7$, sig. $\left.=0.000\right)$, stretch out during work (Pearson chi-square $=8.149, d_{f}=2$, sig. $=0.017)$. The existence of health problems with computer work does not show a significant relation. $75.2 \%$ of females use a notebook and $11.3 \%$ a desktop computer, while the figures are $56.6 \%$ and $30.3 \%$ among males. Keeping the notebook in the lap is rather typical among females (35.6\%) than males (15.0\%). Stretch out, as well as a perceived health problem is more typical among males.

There is a significant relationship between the level of studies and room type (Pearson chi-square $=27.794, d_{f}=10$, sig. $=0.002$ ) and health problems perceived (Pearson chisquare $=16.005, d_{f}=4$, sig. $\left.=0.003\right)$. The bedroom is less used by master level students $(46.7 \%)$ than those at a lower-level $(68.9 \%)$. Health problems are perceived by $22.7 \%$ of master level students and by $12.2 \%$ of who study at the bachelor or the vocational levels.

Work experience is related significantly with room type (Pearson chi-square $=59.760, d_{f}=10$, sig. $\left.=0.000\right)$, existence of health problems (Pearson chi-square $=12.020$, $d_{f}=4$, sig. $=0.017$ ) and stretch out during work (Pearson chi-square $=31.438, d_{f}=4$, sig. $=0.000$ ). The bedroom is less popular for computer work among students with work experience $(55.2 \%)$ than ones without it (79.3\%). Health problems are perceived by $16.7 \%$ of students with work experience and by $11.2 \%$ of whom do not work.

ANOVA is conducted to check other relations. Since the data are available on the ordinal scale, the analysis uses the non-parametric Kruskal-Wallis H (K-W H) test. Gender and work experience show significant effects on time spent with different computer types and tiredness. The level of studies influences tiredness in the eyes and neck significantly. Table 7 summarizes the significant issues.

A more substantial proportion of females than males prefer a notebook to a desktop computer, but they spend less time with it. Higher values in exhausting and tiring characteristics are found:

- among females compared to males,

- among master level students compared to bachelor and vocational ones,

- among students with work experience to ones who do not have any.

Table 7 Significant relations based on ANOVA

\begin{tabular}{|c|c|c|c|}
\hline & Factors & K-W H & sig. \\
\hline \multirow{9}{*}{$\begin{array}{l}\dot{\bar{d}} \\
\stackrel{\overrightarrow{0}}{0}\end{array}$} & Notebook use & 4.953 & 0.026 \\
\hline & Smartphone use & 15.198 & 0.000 \\
\hline & Air freshness & 9.538 & 0.002 \\
\hline & Tiredness, eyes & 36.955 & 0.000 \\
\hline & Tiredness, hand, and arms & 8.339 & 0.004 \\
\hline & Tiredness, back, and shoulder & 65.274 & 0.000 \\
\hline & Tiredness, neck & 33.839 & 0.000 \\
\hline & Tiredness, waist & 10.862 & 0.001 \\
\hline & Exhausting computer work & 14.388 & 0.000 \\
\hline \multirow{7}{*}{ 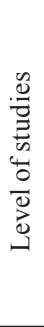 } & Notebook use & 23.617 & 0.000 \\
\hline & Smartphone use & 33.881 & 0.000 \\
\hline & Watching TV & 12.231 & 0.002 \\
\hline & The temperature of the room & 6.711 & 0.035 \\
\hline & Tiredness, eyes & 18.156 & 0.000 \\
\hline & Tiredness, neck & 6.968 & 0.031 \\
\hline & Exhausting computer work & 6.908 & 0.032 \\
\hline \multirow{9}{*}{ 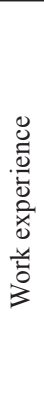 } & Desktop computer use & 67.195 & 0.000 \\
\hline & Notebook use & 7.211 & 0.027 \\
\hline & Smartphone use & 15.443 & 0.000 \\
\hline & Tiredness, eyes & 9.200 & 0.010 \\
\hline & Tiredness, hand, and arms & 11.063 & 0.004 \\
\hline & Tiredness, back, and shoulder & 7.142 & 0.028 \\
\hline & Tiredness, fingers & 9.840 & 0.007 \\
\hline & Tiredness, waist & 6.303 & 0.043 \\
\hline & Exhausting computer work & 16.244 & 0.000 \\
\hline
\end{tabular}


Results suggest running a cluster analysis based on feeling tiredness and exhausting characteristic of computer work. The hierarchical cluster with Ward's methods results in two clusters. The ANOVA test shows a significant effect of cluster membership on satisfaction with the work environment, and cross-tabulation conforms to a significant difference in health problems due to regular computer work by cluster membership. There are not remarkable and significant differences neither by the grouping variables nor the characteristics of the workplace. Cluster analysis confirmed other related investigations.

Correlation analysis (Spearman's rho) between the various factors of satisfaction with the work environment and exhausting characteristics of computer work show significant positive but most times moderate or weak results within the groups and a significant negative but weak result between the factors of the two groups. Highest (negative) values results between the groups are found between sitting position and neck and waist. Tables 8 to 10 summarize the results.

\subsection{Discussion of the results}

The analysis of computer-related health problems has long been at the center of interest. Musculoskeletal problems (Hales et al., 1994), back and neck pain (Adedoyin et al., 2005), as well as computer vision syndrome (Akinbinu and Mashalla, 2014), are in the focus of medical literature. Teo et al. (2019) confirm the relation between neck pain and computer vision syndrome. Although the numerical results of the studies may differ,

Table 8 Correlation coefficients, exhausting characteristics (Spearman's rho, sig. $=0.000, n=711$ )

\begin{tabular}{|c|c|c|c|c|c|c|}
\hline & Eyes & Hands and arms & Fingers & Back and shoulders & Neck & Waist \\
\hline Eyes & & 0.317 & 0.274 & 0.395 & 0.443 & 0.407 \\
\hline Hands and arms & 0.317 & & 0.649 & 0.448 & 0.492 & 0.403 \\
\hline Fingers & 0.274 & 0.649 & & 0.390 & 0.409 & 0.388 \\
\hline Back and shoulders & 0.395 & 0.448 & 0.390 & & 0.750 & 0.640 \\
\hline Neck & 0.443 & 0.492 & 0.409 & 0.750 & & 0.609 \\
\hline Waist & 0.407 & 0.403 & 0.388 & 0.640 & 0.609 & \\
\hline
\end{tabular}

Table 9 Correlation coefficients, exhausting characteristics (Spearman's rho, sig. $=0.000, n=711$ )

\begin{tabular}{lcccccccc}
\hline & Ergonomics of tools & Size of desk & Available space & Light & Sitting position & Temperature & Air freshness \\
\hline Ergonomics of tools & & 0.352 & 0.301 & 0.336 & 0.392 & 0.282 \\
Size of desk & 0.352 & & 0.675 & 0.471 & 0.474 & 0.294 \\
Available space & 0.301 & 0.675 & & 0.518 & 0.453 & 0.536 \\
Light & 0.336 & 0.471 & 0.518 & 0.416 & 0.517 \\
Sitting position & 0.392 & 0.474 & 0.453 & 0.536 & 0.502 \\
Temperature & 0.282 & 0.391 & 0.416 & 0.517 & 0.502 & 0.461 \\
Air freshness & 0.294 & 0.405 & 0.460 & 0.503 & 0.461 & 0.628 \\
\hline
\end{tabular}

Table 10 Correlation coefficients between factor groups (Spearman's rho, $n=711$ )

\begin{tabular}{|c|c|c|c|c|c|c|c|}
\hline & Ergonomics of tools & Size of desk & Available space & Light & Sitting position & Temperature & Air freshness \\
\hline Eyes & -0.123 & -0.020 & -0.018 & 0.013 & -0.099 & -0.061 & -0.063 \\
\hline sig. & 0.001 & 0.594 & 0.638 & 0.726 & 0.008 & 0.107 & 0.096 \\
\hline Hands, arms & -0.072 & -0.097 & -0.090 & -0.085 & -0.187 & -0.145 & -0.117 \\
\hline sig. & 0.054 & 0.009 & 0.016 & 0.024 & 0.000 & 0.000 & 0.002 \\
\hline Fingers & -0.116 & -0.048 & -0.079 & -0.074 & -0.161 & -0.146 & -0.120 \\
\hline sig. & 0.002 & 0.203 & 0.035 & 0.048 & 0.000 & 0.000 & 0.001 \\
\hline Back and shoulders & -0.169 & -0.020 & 0.007 & -0.023 & -0.182 & -0.061 & -0.014 \\
\hline sig. & 0.000 & 0.588 & 0.852 & 0.546 & 0.000 & 0.101 & 0.717 \\
\hline Neck & -0.160 & -0.050 & -0.029 & -0.056 & -0.207 & -0.103 & -0.061 \\
\hline sig. & 0.000 & 0.179 & 0.433 & 0.138 & 0.000 & 0.006 & 0.102 \\
\hline Waist & -0.183 & -0.104 & -0.087 & -0.087 & -0.208 & -0.130 & -0.111 \\
\hline sig. & 0.000 & 0.006 & 0.020 & 0.021 & 0.000 & 0.001 & 0.003 \\
\hline
\end{tabular}


the conclusions of the studies agree that the root cause of the problems is computer work. The findings of the present study are in harmony with the related studies with reference in Subsections 2.1 and 2.2, but a direct comparison of the results is not feasible because of the different approaches of the analysis (self-evaluation). Considering the complexity of the field, a less in-depth, but overall exploration of the health impact of the human-computer interactions responds to a literature gap.

Both ANOVA and correlation analyses confirm the complexity of the problems. Most of the correlation coefficients between the factors of exhausting characteristics show a remarkable and significant relationship as well as in case of the satisfaction with the work environment. At the same time, correlation coefficients between the factor groups are weak and often negative even they are significant, suggesting that the majority of the respondents do not perceive a relation between the working environment and the health impact.

\section{Conclusions}

The concept of the research aims to explore the ergonomics aspects of computer activities and to find relationships between workplace design, work performance, and health impact. The survey conducted allowed a thorough data collection regarding habits, attitudes, and satisfaction. The respondents prefer mobile devices to desktop computers. The study confirms that inadequate workplace design is typical among the students, and it usually leads to a harmful sitting posture. Although, students evaluate their workplace and environment very good.

Trends in ICT development, especially mobilization, is expected to be continued, while the human body is unchanged. The versatility of the attention to the field in the literature proves the complexity of the problem. The results presented in the paper may contribute to expanding the knowledge base of human-computer

\section{References}

Adedoyin, R. A., Idowu, B. O., Adagunodo, R. E., Owoyomi, A. A., Idowu, P. A. (2005) "Musculoskeletal pain associated with the use of computer systems in Nigeria", Technology and Health Care: Official Journal of the European Society for Engineering and Medicine, 13(2), pp. 125-130. [online] Available at: https://www. ncbi.nlm.nih.gov/pubmed/15912010 [Accessed: 10 May 2019]

Akinbinu, T. R., Mashalla, Y. J. (2014) "Impact of Computer Technology on Health: Computer Vision Syndrome (CVS)", Medical Practice Review, 5(3), pp. 20-30. https://doi.org/10.5897/MPR.2014.0121 interactions. Higher education programs can contribute to the more effective and gentler computer work in two ways. On the one hand, the task of education is informing students about the risks through ergonomics lessons; on the other hand, presenting the best practices and guiding the students to a conscious approach to human-computer interactions. Understanding computer usage patterns and personal aspects facilitate the implementation of targeted improvement actions.

Along the presumptions of the study, the following conclusion can be drawn.

Mobilization and workplace design: The results confirm the presumption about the mobilization of computer work. The preference of notebooks to a desktop computer, the spread and the extension of mobile internet usage are pieces of evidence of the phenomenon. Unfortunately, notebooks do not allow the establishment of an ideal workplace. According to the results of workplace design and work environment evaluation, an uncomfortable sitting position is common among the respondents.

Health problems: The results confirm that inadequate workplace design goes with increased health problems.

Grouping possibilities: several grouping factors show effects on the results. There are significant differences found, but the general attributions of the respondents could not separate demarcated profiles. By gender, females have more serious exposure to health risks due to worse conditions of computer workplace and computer type selections.

Chain of impacts: The results show that there is a weak but significant correlation between the satisfaction with the work environment and the perceived health impacts (tiredness). The respondents are mostly satisfied with their work environment regardless of their characteristics. Students with presumably more experience with computer work are rather affected by problems that may be related to higher exposure and a greater workload.

Alexander, L. M., Currie, C. (2004) "Young people's computer use: implications for health education", Health Education, 104(4), pp. 254-261. https://doi.org/10.1108/09654280410546745

Anshel, J. (2005) "Visual Ergonomics Handbook", CRC Press, Boca Raton, FL, USA. https://doi.org/10.1201/9781420032055

Assimakopoulos, V. D., Stathopoulou, O. I., Halios, C., Helmis, C. G. (2008) "Numerical Investigation of the Indoor Environmental Conditions in an Office", International Journal of Ventilation, 6(4), pp. 315-326. https://doi.org/10.1080/14733315.2008.11683787 
Asundi, K., Odell, D., Luce, A., Dennerlein, J. T. (2012) "Changes in posture through the use of simple inclines with notebook computers placed on a standard desk", Applied Ergonomics, 43(2), pp. 400-407.

https://doi.org/10.1016/j.apergo.2011.06.013

Baranyi, Sz., Hercegfi, K., Tilly, K. (2003) "Invariant User Interfaces", PeriodicaPolytechnicaElectricalEngineering,47(3-4),pp.297-309. [online] Available at: https://pp.bme.hu/ee/article/view/958 [Accessed: 14 January 2019]

Berényi, L. (2013) "Számítógépes munkahelyek ergonómiája a gyakorlatban" (Ergonomics of computer workplaces), Marketing \& Menedzsment, 47(3), pp. 76-86. [online] Available at: https://journals.lib.pte.hu/index.php/mm/article/view/650 [Accessed: 11 February 2019] (in Hungarian)

Berényi, L., Szolnoki, B., Bánhegyesi, L. (2015) "Office work: Ergonomic and medical aspect", European Scientific Journal, 11(2), pp. 21-33. [online] Available at: https://eujournal.org/index.php/esj/article/ view/4959 [Accessed: 11 February 2019]

Corlett, E. N., Wilson, J. R., Manenica, I. (1986) "The Ergonomics of Working Postures: Models, Methods And Cases: The Proceedings Of The First International Occupational Ergonomics Symposium, Zadar, Yugoslavia, 15-17 April 1985", Taylor \& Francis, Philadelphia, PA, USA.

Davis, E. (2012) "Fundraising and the Next Generation: Tools for Engaging the Next Generation of Philanthropists", John Wiley \& Sons, Hoboken, NJ, USA.

De Korte, E., Kuijt-Evers, L., Vink, P. (2007) "Effects of the Office Environment on Health and Productivity 1: Auditory and Visual Distraction", In: Dainoff, M. J. (ed.) Ergonomics and Health Aspects of Work with Computers (EHAWC 2007), Springer, Berlin, Heidelberg, Germany, pp. 26-33. https://doi.org/10.1007/978-3-540-73333-1_4

Dix, A. (2017) "Human-computer interaction, foundations and new paradigms", Journal of Visual Languages \& Computing, 42, pp. 122-134. https://doi.org/10.1016/j.jvlc.2016.04.001

Gowrisankaran, S., Sheedy, J. E. (2015) "Computer vision syndrome: A review", Work, 52(2), pp. 303-314. https://doi.org/10.3233/WOR-152162

Hales, T. R., Sauter, S. L., Peterson, M. R., Fine, L. J., Putz-Anderson, V., Schleifer, L. R., Ochs, T. T., Bernard, B. P. (1994) "Musculoskeletal disorders among visual display terminal users in a telecommunications company", Ergonomics, 37(10), pp. 1603-1621. https://doi.org/10.1080/00140139408964940

Kearney, D. S. (2008) "Ergonomics made easy: A checklist approach", Government Institutes, Lanham, MD, USA.

Khan, R., Surti, A., Rehman, R., Ali, U. (2012) "Knowledge and practices of ergonomics in computer users", Journal of Pakistan Medical Association, 62(3), pp. 213-217. [online] Available at: https://jpma.org.pk/article-details/3293?article_id=3293 [Accessed: 10 October 2019]

Khurana, A. (2009) "Scientific management: A Management Idea to Reach a Mass Audience", Global India Pub, New Delhi, India.

Kroemer, K. H. E., Kroemer, A. D. (2001) "Office ergonomics", Taylor \& Francis, London, UK.

Kroemer, K. H. E., Kroemer, H. B., Kroemer-Elbert, K. E. (2001) "Ergonomics: How to design for ease and efficiency", Prentice Hall, Upper Saddle River, NJ, USA.
Laeser, K. L., Maxwell, L. E., Hedge, A. (1998) "The Effect of Computer Workstation Design on Student Posture", Journal of Research on Computing in Education, 31(2), pp. 173-188. https://doi.org/10.1080/08886504.1998.10782249

Larsen, M. K., Samani, A., Madeleine, P., Olsen, H. B., Søgaard, K., Holtermann, A. (2009) "Short-term effects of implemented high intensity shoulder elevation during computer work", BMC Musculoskeletal Disorders, 10(1), Article Number: 101. https://doi.org/10.1186/1471-2474-10-101

McKeown, C. (2008) "Office Ergonomics: Practical Applications", CRC Press, Boca Raton, FL, USA.

Mork, P. J., Westgaard, R. H. (2007) "The influence of body posture, arm movement, and work stress on trapezius activity during computer work", European Journal of Applied Physiology, 101(4), pp. 445-456. https://doi.org/10.1007/s00421-007-0518-4

Murrell, K. F. H. (1965) "Ergonomics: Man in His Working Environment", Chapman and Hall, London, UK.

https://doi.org/10.1007/978-94-009-5878-4

Nag, P. K. (2019) "Office Buildings: Health, Safety and Environment", Springer Nature, Singapore, Singapore. https://doi.org/10.1007/978-981-13-2577-9

Robertson, M., Amick, B. C., DeRango, K., Rooney, T., Bazzani, L., Harrist, R., Moore, A. (2009) "The effects of an office ergonomics training and chair intervention on worker knowledge, behavior and musculoskeletal risk", Applied Ergonomics, 40(1), pp. 124-135. https://doi.org/10.1016/j.apergo.2007.12.009

Rogers, Y., Sharp, H., Preece, J. (2011) "Interaction Design: Beyond Human-Computer Interaction", John Wiley \& Sons, Chichester, UK.

Rosenfield, M. (2011) "Computer vision syndrome: a review of ocular causes and potential treatments", Ophthalmic \& Physiological Optics, 31(5), pp. 502-515. https://doi.org/10.1111/j.1475-1313.2011.00834.x

Seghers, J., Jochem, A., Spaepen, A. (2003) "Posture, muscle activity and muscle fatigue in prolonged VDT work at different screen height settings", Ergonomics, 46(7), pp. 714-730. https://doi.org/10.1080/0014013031000090107

Shikdar, A. A., Al-Kindi, M. A. (2007) "Office Ergonomics: Deficiencies in Computer Workstation Design", International Journal of Occupational Safety and Ergonomics, 13(2), pp. 215-223. https://doi.org/10.1080/10803548.2007.11076722

Teo, C., Giffard, P., Johnston, V., Treleaven, J. (2019) "Computer vision symptoms in people with and without neck pain", Applied Ergonomics, 80, pp. 50-56.

https://doi.org/10.1016/j.apergo.2019.04.010

Turgut, B. (2018) "Ocular Ergonomics for the Computer Vision Syndrome", Journal of Eye and Vision, 1(1), pp. 1-2. [online] Available at: http:// www.imedpub.com/articles/ocular-ergonomics-for-the-computervision-syndrome.pdf [Accessed: 10 October 2019]

Turner, J. A., Karasek, R. A. (1984) "Software ergonomics: effects of computer application design parameters on operator task performance and health", Ergonomics, 27(6), pp. 663-690. https://doi.org/10.1080/00140138408963539

Wærsted, M., Hanvold, T. N., Veiersted, K. B. (2010) "Computer work and musculoskeletal disorders of the neck and upper extremity: A systematic review", BMC Musculoskeletal Disorders, 11(1), Article Number: 79

https://doi.org/10.1186/1471-2474-11-79 
Wilson, J. R. (2014) "Fundamentals of systems ergonomics/human factors", Applied Ergonomics, 45(1), pp. 5-13.

https://doi.org/10.1016/j.apergo.2013.03.021

Woo, E. H. C., White, P., Lai, C. W. K. (2016) "Ergonomics standards and guidelines for computer workstation design and the impact on users' health - a review", Ergonomics, 59(3), pp. 464-475. https://doi.org/10.1080/00140139.2015.1076528

Yang, J. F., Cho, C. Y. (2012) "Comparison of posture and muscle control pattern between male and female computer users with musculoskeletal symptoms", Applied Ergonomics, 43(4), pp. 785-791. https://doi.org/10.1016/j.apergo.2011.11.013
Yang, H. B., Sang, G. S., Feng, Y. T. (2013) "Health Office Chair Design Based on Ergonomics", Applied Mechanics and Materials, 274, pp. 517-522.

https://doi.org/10.4028/www.scientific.net/AMM.274.517

York, J., Pendharkar, P. C. (2004) "Human-computer interaction issues for mobile computing in a variable work context", Journal of Human-Computer Studies, 60(5-6), pp. 771-797. https://doi.org/10.1016/j.ijhcs.2003.07.004

Zemke, R., Raines, C., Filipczak, B. (2013) "Generations at work: Managing the CLASH of Boomers, Gen Xers, and Gen Yers in the Workplace", American Management Association, New York, NY, USA. 